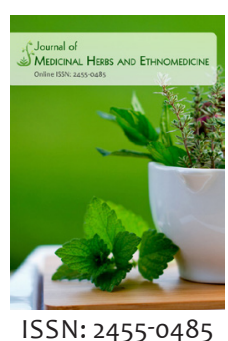

Received: May 18, 2020 Revised: June 13, 2020 Accepted: June 16, 2020 Published: June 25, 2020

*Corresponding Author: Gülşen Kaya,

Email: gulsen.kaya@inonu. edu.tr

\section{Biochemical properties and urease, $\alpha$-amylase inhibitory effects of Ocimum basilicum L. (Reyhan)}

\author{
Gülșen Kaya'*, Merve Keskin² \\ 'Petroleum Analysis Laboratory, Inonu University, Malatya, Turkey, ${ }^{2}$ Vocational School of Health Services, Bilecik \\ Şeyh Edebali University, Bilecik, Turkey
}

\begin{abstract}
With the understanding of the role of antioxidants in preventing degenerative and age-related diseases caused by oxidative stress, and taking into account the multitude of pharmacological applications such as antidiabetic, antifungal, cardioprotection, immunostimulant, interest in plants rich in this respect has increased. Ocimum basilicum L. (purple) is a one-year, fragrant spice herb with its own aroma. In this study, chemical characterization of Ocimum basilicum plant was performed and inhibition effects on urease and a-amylase were investigated. Total phenolic content of Ocimum basilicum leafs ethanolic and water extracts were $320.08 \pm 2.03,388.15 \pm 1.05 \mathrm{mg}$ GAE/100g; total flavonoids were $282.57 \pm 1.12,307.75 \pm 0.89 \mathrm{mg} \mathrm{QE} / 100 \mathrm{~g}$; antioxidant capacity of samples were $0.46 \pm 0.01$ and $0.52 \pm 0.02 \mathrm{mM} \mathrm{Fe}+2 /$ $\mathrm{mg}$ extract, $0.46 \pm 0.01 ; \mathrm{IC}_{50}$ values of urease were $18.77 \pm 0.22,20.19 \pm 0.15 \mu \mathrm{g} / \mathrm{mL}$ and $\mathrm{IC}_{50}$ values of $\alpha$-amylase were $0.47 \pm 0.01,0.42 \pm 0.01 \mu \mathrm{g} / \mathrm{mL}$, respectively. It is determined that ethanolic extract of leaves is rich in linalool, linolenin, phytol and $\alpha$-humulene. The data show that the leaves of the plant may be effective on two important diseases such as Diabetes mellitus and $H$. pylori.
\end{abstract}

KEYWORDS: Inhibition, Urease, $\alpha$-amylase, Phenolics

\section{INTRODUCTION}

Medicinal and aromatic plants have been used from ancient times. These plants, which people benefit from, have a certain appearance, color, smell, use as food and spice, and consume as a medicine. It is very old that people can cure diseases with plants. The vast majority of new chemicals discovered by today's modern sciences are of vegetable origin. Drugs that allow treatment of many diseases in the medical world are being produced and developed from herbal substances [1]. The basil, called Ocimum basilicum is a one-year fragrant spice herb with its own aroma. This plant, originating from Iran, South Asia, and especially India, grows naturally in places with a Mediterranean climate and a warm climate, but is also cultivated in France, Italy and Spain [2-3]. Ocimum basilicum has a wide morphological and chemical variation within the species. Therefore, it is divided into many subspecies and varieties and examined. In some regions, especially in eastern provinces, purple types are common and are called purple basil. Green varieties known as 'sweet basil' in the foreign literature, which is more common in western provinces, are called basil (Ocimum basilicum) [4].

Essential oil obtained from the flowering branches of basil plant, soothing in medicine, diuretic, degassing, urinary tract antiseptic, pain reliever, expectorant, worm reducer, calming, cough suppressant, mouth and dental complaints, diarrhea and chronic dysentery, respiratory diseases and it is effective in the treatment of fungal disease [5]. It is also used as a repellent to protect against invigorating baths, toothpastes, mouthwashes and insects, has an antimicrobial, antifungal effect [6,7]. It is known to be gastric, diuretic and anthelmintic and beneficial in heart and brain related disorders. These properties of basil can make it an important material in traditional and complementary medicine applications.

Inhibition effects on urease and $\alpha$-amylase enzymes have been investigated lately. H. pylori infection is usually an important factor causing chronic gastritis, gastro duodenal ulcer, and lymphoid tissue lymphoma due to low-grade gastric mucosa. Epidemiological data show that the high $\mathrm{H}$. pylori infection rate causes gastric cancer and adenocarcinoma incidence $[8,9]$. Urease catalyzes the hydrolysis of urea into ammonium and carbon dioxide, and its most important role is to protect bacteria in the acidic environment of the stomach [10]. Also, ammonia and monochloramine, a reaction product of ammonia and hypochloric acid, have been reported to exhibit strong toxicity in the gastric epithelium [11]. In addition, H. pylori lacking urease activity has been shown to not cause infection in animal models. Therefore,

Copyright: ( ) The authors. This article is open access and licensed under the terms of the Creative Commons Attribution License (http://creativecommons.org/licenses/by/4.0/) which permits unrestricted, use, distribution and reproduction in any medium, or format for any purpose, even commercially provided the work is properly cited. Attribution - You must give appropriate credit, provide a link to the license, and indicate if changes were made. 
inhibition of urease is important. Diabetes, obesity and oxidative stress are metabolic and degenerative disorders that have longterm effects. Diabetes occurs when not enough insulin is produced (type-1). Diabetes is the main cause of a number of complications such as blindness, heart attack, lower limb amputation and kidney failure [12]. Type-2 diabetes is the dominant form of diabetes. Inhibition of pancreatic amylase can be effective in controlling postprandial sugar levels in patients with diabetes [13].

In this study, biochemical characterization of water and ethanolic extracts prepared from purple Ocimum basilicum was determined. The inhibition effect of the extracts on urease and $\alpha$-amylase enzymes was also studied.

\section{MATERIAL AND METHODS}

\section{Preparation of Plant Extracts}

Ocimum basilicum L. was freshly supplied by commercial from Malatya, Turkey in the cultivation season of 2019. Leaves were air dried in a shady place. Ten grams of dried samples of leaves were separately placed in a flask with $100 \mathrm{~mL}$ ethanol (99\%) and stirred at room temperature for $24 \mathrm{~h}$, then sonicated for $2 \mathrm{~h}$ with an ultrasonicator (ultrasonic Elma Schmidbauer GmbH, Germany). The mixtures were filtered with filter paper (Whatman) and concentrated in a rotary evaporator (IKAWerke, Staufen, Germany) at $40^{\circ} \mathrm{C}$. Water extract of Ocimum basilicum L. was obtained as same method. The residues were then individually resolved with a minimal volume of ethanol and kept at $4{ }^{\circ} \mathrm{C}$ until used.

\section{Determination of Total Phenolics}

The total phenolic content of Ocimum basilicum L. extract was determined by using the Folin- Ciocalteu method [14,15]. A calibration plot was prepared using the Gallic acid (GA) standard and the results were expressed in mg GAE / $100 \mathrm{~g}$ in Gallic acid equivalent.

\section{Determination of Total Flavanoid}

Determination of total flavonoid content was made according to [16]. Quercetin (QE) was used as standard and total flavanoid content was expressed in $\mathrm{mg}$ QE / $100 \mathrm{~g}$.

\section{Determination of Antioxidant Activity}

Antioxidant activity of Ocimum basilicum L exracts was determined by using ferric reducing antioxidant power (FRAP) [17].

\section{GC-MS Analysis}

Main chemical composition of ethanolic Ocimum basilicum extract was determined with Gas chromatography coupled with mass spectrometry. Derivatization of extracts was carried out by using N-Methyl-N-(trimethylsiliyl)-trifluoroacetamide (MSTFA). Shortly, Ocimum basilicum extract was dried by using rotary evaporator and $5 \mathrm{mg}$ of dried residue was mixed with $50 \mu \mathrm{L}$ of dry pyridine and $75 \mu \mathrm{L}$ of MSTFA. This reaction mixture was heated at $80^{\circ} \mathrm{C}$ for $20 \mathrm{~min}$. GC-MS analysis was applied with an Agilent 7890A GC system equipped with HP5-MS capillary column $\left(30 \mathrm{~m}^{*} 0.25 \mathrm{~mm} * 0.5 \mathrm{~mm}\right)$. The oven temperature was programmed from 75 to $325^{\circ} \mathrm{C}$ at a rate of $5^{\circ} \mathrm{C} / \mathrm{min}$, and a $15 \mathrm{~min}$ hold at $325^{\circ} \mathrm{C}$. Helium was used as a carrier gas at a flow rate of $0.8 \mathrm{~mL} / \mathrm{min}$. The split ratio was $1: 50$, the injector temperature $300^{\circ} \mathrm{C}$, and the ionization voltage $70 \mathrm{eV}$ [18]. Identification of the compounds was performed using commercial libraries as Wiley.

\section{Determination of $\alpha$-amylase Inhibition}

$\alpha$-amylase activity was assayed according to the modified DNS method described by [19]. Reaction mixture containing $300 \mu \mathrm{L}$ of $1 \%$ soluble starch and $300 \mu \mathrm{L}$ of enzyme solution was incubated for $30 \mathrm{~min}$ at $35^{\circ} \mathrm{C}$. Equal volume of DNS reagent was added into tubes and kept in a boiling water bath to quantify generated reducing sugars as glucose equivalent. All characterization assays were performed in triplicate. $\mathrm{IC}_{50}$ value of the extracts was determined at five different extract concentrations at standard assay condition and dose response curve was generated [20]. Acarbose was used as reference inhibitor.

\section{Determination of Urease Inhibition}

Urease activity was determined according to [21]. This method is based on the determination of the amount of ammonia released from urea by the action of urease enzyme by using the indo phenol method that has an absorbance of $625 \mathrm{~nm}$ (Weatherburn). Shortly, reaction mixture contained $5 \mu \mathrm{L}$ of urea solution $(100 \mathrm{mM}), 40 \mu \mathrm{L}$ of jack bean urease and $5 \mu \mathrm{L}$ of buffer $\left(0.01 \mathrm{M} \mathrm{KH}_{2} \mathrm{PO}_{4}, 1 \mathrm{mM}\right.$ EDTA and $0.01 \mathrm{M} \mathrm{LiCl}$; $\mathrm{pH}$ 8.2). After incubation at $35^{\circ} \mathrm{C} 15 \mathrm{~min}, 750 \mu \mathrm{L}$ of phenol reagent $(1 \% \mathrm{w} / \mathrm{v}$ phenol and $0.005 \% \mathrm{w} / \mathrm{v}$ sodium nitroprusside) was added, vortexed and then, $750 \mu \mathrm{L}$ of alkali reagent $(0.5 \%$ $\mathrm{w} / \mathrm{v} \mathrm{NaOH}$ and $0.1 \% \mathrm{v} / \mathrm{v} \mathrm{NaOCl}$ ) was added and vortexed. This mixture was incubated for $15 \mathrm{~min}$ more at $35^{\circ} \mathrm{C}$ and optical densitywas measured at $625 \mathrm{~nm}$ against a blank solution including distilled water instead of enzyme. For the determination of the $\mathrm{IC}_{50}$ value of the extracts, activity assays were conducted at five different extract concentrations and dose response curve was generated [20]. Thiourea was used as standard inhibitor.

\section{RESULTS}

Total phenolic content of Ocimum basilicum leaf ethanolic and water extracts were $320.08 \pm 2.03,388.15 \pm 1.05 \mathrm{mg}$ GAE/100g; total flavonoids were $282.57 \pm 1.12$, 307.75 \pm 0.89 $\mathrm{mg}$ QE/100g; antioxidant capacity of samples were $0.46 \pm 0.01$ and $0.52 \pm 0.02 \mathrm{mM} \mathrm{Fe}^{+2} / \mathrm{mg}$ extract, $\mathrm{IC}_{50}$ values of urease were $18.77 \pm 0.22,20.19 \pm 0.15 \mu \mathrm{g} / \mathrm{mL}$ and $\mathrm{IC}_{50}$ values of $\alpha$-amylase were $0.47 \pm 0.01,0.42 \pm 0.01 \mu \mathrm{g} / \mathrm{mL}$, respectively (Table 1 ). It is determined that ethanolic extract of leaves is rich in linalool, linolenin, phytol and $\alpha$-humulene (Table 2). 
Table 1: Biochemical properties of Ocimum basilicum extract

\begin{tabular}{|c|c|c|c|c|c|}
\hline Ocimum basilicum & $\begin{array}{c}\text { Total phenolic content } \\
\text { mg GAE/100g }\end{array}$ & $\begin{array}{c}\text { Total Flavanoid } \\
\text { content } \mathrm{mg} Q \mathrm{QE} / 100 \mathrm{~g}\end{array}$ & $\begin{array}{c}\text { Antioxidant capacity } \\
\text { FRAP } \mathrm{mM} \mathrm{Fe}+2 / \mathrm{mg} \text { extract }\end{array}$ & Urease $\mathrm{IC}_{50} \mu \mathrm{g} / \mathrm{mL}$ & $\begin{array}{l}\alpha \text {-amylase } \\
\mathrm{IC}_{50} \mu \mathrm{g} / \mathrm{mL}\end{array}$ \\
\hline Leaf EE & $320.08 \pm 2.03$ & $282.57 \pm 1.12$ & $0.46 \pm 0.01$ & $1.877 \pm 0.22$ & $0.47 \pm 0.01$ \\
\hline Leaf WE & $388.15 \pm 1.05$ & $307.75 \pm 0.89$ & $0.52 \pm 0.02$ & $2.019 \pm 0.15$ & $0.42 \pm 0.01$ \\
\hline Acarbose & & & & & $0.31 \pm 0.04$ \\
\hline Thiourea & & & & $1.00 \pm 0.01$ & \\
\hline
\end{tabular}

E: Ethanolic exract WE: Water extract

Table 2: Chemical characterization of 0cimum basilicum extract

\begin{tabular}{lc}
\hline Compounds & Leaf EE Area \% \\
\hline Ocimene & 1.02 \\
Neophytadiene & 2.11 \\
n-Butylphthalate 0.88 & 0.72 \\
2-Hexadecanoic acid & 6.25 \\
6-Octadecenoic acid & 0.98 \\
2,3-Beta quinoline & 0.11 \\
Oxirane & 2.16 \\
Linolenin & 10.27 \\
Linalool & 18.52 \\
Tetradecanal & 0.88 \\
1,2-Benzenedicarboxylic acid & 1.73 \\
Farnesol & 2.07 \\
Trans-alpha-bergamotene & 1.04 \\
Alpha-humulene & 2.62 \\
Caryophyllene & 0.21 \\
12,15- Octadecanoic acid & 1.09 \\
Pentadecanoic acid & 0.86 \\
Phytol & 10.45 \\
Octadecanal & 2.19 \\
Hexadecanal & 0.81 \\
Geraniol & 0.66 \\
Pentadecanal & 1.23 \\
Palmitic acid & 1.40 \\
\hline
\end{tabular}

\section{DISCUSSION}

Plants have high antioxidant effect thanks to their secondary metabolites. With the increasing interest in traditional and complementary medicine practices, the rate of benefiting from these features of plants has increased. Purple basil is a pleasant fragrance and colorful plant used in daily life. Studies show that this plant has a high antioxidant effect and inhibits $\alpha$-amylase and urease enzymes.

Gülçin et al. [22] reported that the possible radical scavenging and antioxidant activity of basil's water (WEB) and ethanol extracts (EEB) were investigated using different antioxidant methodologies. Total antioxidant activity was found at a concentration of $50 \mu \mathrm{g} / \mathrm{mL}$ made according to the ferric thiocyanate method, and the inhibition effects of WEB and EEB on peroxidation of linoleic acid emulsion were $94.8 \%$ and $97.5 \%$, respectively. Additional total phenolic content of basil extracts was determined as gallic acid equivalent and found to be equivalent.

Rezzoug et al. [23] investigated the antioxidant and antimicrobial activities of the ethanolic extracts (EE) and essential oils (EO) of two species from the Lamiaceae family, Ocimum basilicum and Thymus algeriensis Boiss. Phenolic compounds found in ethanol extracts from both plants were analyzed by HPLC and showed a rich flavonoid content. Chemical analysis of essential oil from Ocimum basilicum revealed 26 unique compounds with linalool (52.1\%) and linalyl acetate (19.1\%) as main compounds.

Khair-ul-Bariyah et al. [24] compared some phytochemical parameters of Ocimum, O. basilicum and O.sanctum genus in their study. Both plants showed good urease inhibitory activity and $O$. basilicum extracts showed a greater urease activity than O. sanctum extracts. O. basilicum's alpha-amylase inhibitory activity is also higher than that of $O$. sanctum.

Nabati et al. [25] worked with 137 raw extracts and found that Ocimum basilicum (Reyhan-e banafsh) leaves showed 19.61 \pm 0.05 (inhibition \%) and Ocimum basilicum (Reyhan) leaves showed $0.41 \pm 0.01$ (inhibition \%) urease inhibitor activity. Ahmet et al [26] investigated the inhibitory activities of the polar and non-polar extracts of Ocimum basilicum L. leaves and flowers on amylase and lipase (PPL). They determined the chemical components of essential oils and hexane extract by GC/MS (Gas Chromatography-Mass Spectrometry). For amylase inhibition, the $\mathrm{IC}_{50}(\mathrm{~g} / \mathrm{mL})$ of the extracts was found to be $0.27-0.37$, which was found to be close to acarbose.

\section{CONCLUSION}

Ocimum basilicum L. (purple), used as food in daily life, has a powerful antioxidant effect thanks to the secondary metabolites it contains. In this study, the total amount of phenolic content, total flavanoid content and antioxidant capacity of ethanolic and water extracts were determined. It was determined that plant extracts had an inhibition effect on $\alpha$-amylase and urease enzymes. The chemical composition of the ethanolic extract was clarified using GC/MS. The data obtained shows that the leaves of the plant may be effective on two important diseases such as Diabetus mellitus and H. pylori.

\section{REFERENCES}

1. Baytop T. Treatment Plant in Turkey (Past and Present), 2nd Edition Nobel bookstores; 1999.

2. Akgül A.Spice Science and Technology, Food Technology Association Publications No:15. 1993; 451

3. Özcan M, Chalchat JC. Essential Oil Composition of Ocimum basilicum and O. Minimum in Turkey. Czech. J. Food. Sci . 2002; 20 (6): 223-228.

4. Telci I, Bayram E, Yılmaz G, Avcı AB. Local Culture Made in Turkey Basil (Ocimum spp) genotypes Morphological Characterization and selection of superior plants of agronomic and technological properties (Final Report), No. TOGTAG-3102 project. TUBITAK; 2005.

5. Asımgil A. Medicinal Plants, Timaş Publishing Istanbul. 1996; S:352.

6. Skaltsa H, Loukıs A. Analysis of the Essential Oil of Grek Sweet Basil. Laboratory of Pharmacognosy- University of Athens PH. D Thessis; 
1985

7. Erşahin L., Diyarbakır Agronomic and Quality Characteristics of Basil (Ocimum Basilicum L.) Populations Grown in Ecological Conditions. Thesis in Science Bil. Inst of cukurova University. Adana; 2006

8. Kosikowska P, Berlicki L. Urease inhibitors as potential drugs for gastric and urinary tract infections: a patent review. Expert Opin Ther Pat. 2011; 21:945-957.

9. Mobley HL, Hu LT, Foxal PA. Helicobacter pylori urease: properties and role in pathogenesis. Scand J Gastroenterol Suppl. 1991; 187:39-46.

10. Stingl K, Altendorf K, Bakker EP. Acid survival of Helicobacter pylori: how does urease activity trigger cytoplasmic $\mathrm{pH}$ homeostasis? Trends Microbiol. 2002; 10:70-74.

11. Dekigai H, Murakami M, Kita T. Mechanism of Helicobacter pyloriassociated gastric mucosal injury. Dig Dis Sci .1995; 40:13321339.

12. Diabetes: World Health Organization: Geneva, Switzerland; 2019.

13. Serrano M, Bouaid A, Martínez M, Aracil J. Oxidation stability of biodiesel from di erent feedstocks: Influence of commercial additives and purification step. Fuel. 2013; 113: 50-58.

14. Singleton VL, Rossi JA. Colorimetry of total phenolics with phosphomolybdic-phosphotungstic acid reagents. American journal of Enology and Viticulture. 1965; 16(3): 144-158.

15. Singleton VL, Orthofer R, Lamuela-Raventós RM. Analysis of total phenols and other oxidation substrates and antioxidants by means of folin-ciocalteu reagent. In Methods in enzymology. 1999; 299: 152-178. Academic press

16. Fukumoto LR, Mazza G. Assessing antioxidant and prooxidant activities of phenolic compounds. Journal of agricultural and food chemistry.2000; 48(8): 3597-3604.

17. Benzie IF, Strain JJ. Ferric reducing/antioxidant power assay: direct measure of total antioxidant activity of biological fluids and modified version for simultaneous measurement of total antioxidant power and ascorbic acid concentration. In Methods in enzymology. 1999; 299:15-27. Academic Press.
18. Trusheva B, Popova M, Koendhori EB, Tsvetkova I, Naydenski C Bankova V. Indonesian propolis: chemical composition, biological activity and botanical origin. Natural Product Research. 2011; 25(6): 606-613.

19. Bernfeld P. Amylases, alpha and beta. Methods in enzymology.1955; 149-158.

20. Keskin Ş, Şirin Y, Çakir HE, Keskin M. An investigation of Humulus lupulus L.: Phenolic composition, antioxidant capacity and inhibition properties of clinically important enzymes. South African journal of botany. 2019; 120: 170-174.

21. Weatherburn MW. Phenol-hypochlorite reaction for determination of ammonia. Analytical chemistry. 1967; 39(8): 971-974.

22. Gülcin I, Elmastas M, Aboul-Enein HY. Determination of Antioxidant and Radical Scavenging Activity of Basil (Ocimum basilicum L. Family Lamiaceae) Assayed by Different Methodologies. Wiley InterScience Discover Something Great.2007;21:354-361.

23. Rezzoug M, Bakchiche B, Gherib A, Roberta A, Guido F, Kilinçarslan Ö et al. Chemical composition and bioactivity of essential oils and Ethanolic extracts of Ocimum basilicum L. and Thymus algeriensis Boiss. \& Reut. from the Algerian Saharan Atlas. BMC Complementary and Alternative Medicine. 2019;19:146.

24. Khair-ul-Bariyah S, Ahmed D, Ikram Aujla M. Comparative Analysis of Ocimum basilicum and Ocimum sanctum: Extraction Techniques and Urease and alpha-Amylase inhibition. Pakistan Journal of Chemistry.2012; 2(3):1-8.

25. Nabati F, Mojab F, Habibi-Rezaei M, Bagherzadeh K, Amanlou M, Yousefi B. Large scale screening of commonly used Iranian traditional medicinal plants against urease activity. DARU Journal of Pharmaceutical Sciences. 2012; 20:72.

26. Noor Zl, Ahmed A, Rehman HM, Qamar MT, Froeyen M , Ahmad S, et al. In Vitro Antidiabetic, Anti-Obesity and Antioxidant Analysis of Ocimum basilicum Aerial Biomass and in Silico Molecular Docking Simulations with Alpha-Amylase and Lipase Enzymes. MDPI Journal of biology.2019;8:92. 